\title{
ARTICLES
}

\section{The Justification of Basic Rights}

\section{A Discourse-Theoretical Approach ${ }^{*}$}

Rainer Forst

\section{Justifying basic rights}

Very few people doubt that it is a fundamental demand of justice that members of legal-political normative orders ought to have legal rights that define their basic standing as subjects of such an order. ${ }^{1}$ But when it comes to the concrete understanding of such rights, debates abound. What is the nature of these rights - are they an expression of the sovereign will of individuals, or are they based on important human interests? How should these rights be justified - do they have a particular moral ground, and if so, only one or many?

In what follows, I suggest a discourse theory of basic legal rights that answers such questions in a way that I argue is superior to rival approaches, such as a willbased or an interest-based theory of rights. The main argument runs as follows. ${ }^{2}$ Basic rights are reciprocally and generally valid - i.e., mutually justifiable claims $^{3}$ on others (agents or institutions) that they should do or refrain from doing certain things determined by the content of these rights. We call these rights basic or fundamental because they define the status of persons as full members of a normative order in such a way that they provide protection from certain severe forms of legal, political and social domination that endanger equal membership. In my discourse-theoretical understanding (which differs substan-

* Many thanks for their helpful critical remarks to the editors of this journal, Lisette ten Haaf, Elaine Mak and Bertjan Wolthuis, and especially to my critics at the occasion of the VWR conference in June 2016 to whom I will have the pleasure to reply: Laura Valentini, Marcus Düwell, Glen Newey, and Stefan Rummens. Thanks also to Henry Richardson for his written comments and to the participants of the VWR conference and of a workshop at the Free University Berlin where I presented this paper.

1 In the following, I confine myself to the discussion of basic rights of fully recognized members of such an order and leave the important question of the definition of such membership (or the right to it) to one side. I use basic rights in the sense of what is often called constitutional rights (or Grundrechte) within a constitutional regime, though my argument does not assume a written constitution. For a very different usage of the term 'basic rights,' see Henry Shue, Basic Rights: Subsistence, Affluence, and U.S. Foreign Policy (Princeton: Princeton University Press, 1996).

2 The argument in the first two sections overlaps with that of my 'The Point and Ground of Human Rights: A Kantian Constructivist View,' in Global Political Theory, ed. David Held and Pietro Maffettone (Cambridge: Polity, 2016), 22-39.

3 On rights as claims, see esp. Joel Feinberg, 'The Nature and Value of Rights,' The Journal of Value Inquiry 4, no. 4 (1970): 249-51; also Wesley Newcomb Hohfeld, Fundamental Legal Conceptions, ed. W.W. Cook (Clark, NJ: Lawbook Exchange, 2010), 60. 
tially from neo-republican versions), ${ }^{4}$ domination does not primarily mean being denied equal status in the sense of no longer enjoying personal freedom of choice protected from arbitrary interference; rather, it means in a more fundamental sense being disrespected in one's basic claim to be a free and equal normative authority within the order one is subject to. Freedom from domination implies (in a non-instrumental sense) the basic right to co-determine the structure of one's society. This is the status activus, to use Jellinek's term, ${ }^{5}$ of persons as members of a normative order, which is a necessary component of basic rights. Basic rights are not just rights to be passively protected in one's status as a legally, politically and socially non-dominated person; they are, in a reflexive sense, also basic rights to determine the rights and duties that define this status. Being fully protected from non-domination means not being subject to a legal, political and social normative order that denies you equal standing - that is, an order that cannot be properly justified to you as a free and equal member of society, both institutionally and in principle, or, if you prefer, factually in appropriate procedures of justification and counterfactually in our best judgment based on reciprocal and general reasoning. 6

If basic legal rights are reciprocally and generally non-rejectable and fully justifiable between free and equal persons who aim to establish their status as legal, political and social equals protected from domination (thus understood), it follows that there is a particular moral ground for these rights. In a negative sense, this is the moral right not to be subjected to a normative order that denies you basic standing as an equal and that, reflexively speaking, cannot be justified to you as a free and equal person; moreover, positively speaking, it is the right to be an equal normative authority and an active agent of justification when it comes to the basic legal, political and social arrangements in your society - including the basic rights that determine your status. Freedom from domination not only means being respected as someone who enjoys a legally, politically and socially non-dominated equal status secured by certain rights; it also means that whether you enjoy this status or not is not something that is decided by others without the possibility of your involvement. Thus, the authority to define your membership rights must reside in a discursive procedure of reciprocal and general justification in which all participants are justificatory equals.

In essence, the negative and positive formulations employed above coincide in the discourse-theoretical, Kantian idea that those subject to a normative order ought to be equal and free normative authorities who determine that order through discursive procedures of justification in which all can participate as

4 I discuss the difference between my approach and that of Philip Pettit in Rainer Forst, 'A Kantian Republican Conception of Justice as Non-Domination,' in Republican Democracy, ed. Andreas Niederberger and Philipp Schink (Edinburgh: Edinburgh University Press, 2013), 154-68 and Rainer Forst, 'Transnational Justice and Non-Domination: A Discourse-Theoretical Approach,' in Domination Across Borders, ed. Barbara Buckinx et al. (New York: Routledge, 2015), 88-110.

5 Georg Jellinek, System der subjektiven öffentlichen Rechte (Tübingen: Mohr Siebeck, 2011); Robert Alexy, Theorie der Grundrechte (Frankfurt am Main: Suhrkamp, 1986), 229-48.

6 I will come back to the relation between these two levels of justification. 
equals. The main normative concept, therefore, is that of a person as an equal normative authority who has a basic moral claim to be respected in his or her dignity as such an authority - and thus has a basic moral right to justification. ${ }^{7}$ In the present context, this means the basic right to be an equal co-author of the norms to which one is subject and which define one's basic standing in society. The basic right to justification implies not only political rights of participation, but all of those rights that grant you the normative power to ward off and overcome various forms of domination or unjustifiable subjection. Basic rights express this kind of respect for others as equal justificatory authorities; and in a system of properly justified rights, the notion of 'authority' travels from the moral realm to the legal-political domain in the right way (as I will explain below).

The main idea can be formulated in a reflexive way as follows: if basic rights are reciprocally and generally justifiable rights that hold between free and equal persons as members of a normative order, then their very ground is the moral right to be recognized as equal normative authorities when it comes to justifying these rights. For that ground alone (and no other account of values or interests) requires and determines that these rights have to be truly justifiable among justificatory equals. So an important (as it were, recursive) implication of this view is that basic rights include justified claims to participation in a (self-correcting) process through which improved forms of public justification are institutionalized in order to close the gap between real and counterfactual justifications of these rights. The point of these rights is not only to participate in discourse but to improve on the justifications for all definitions of rights, including those that grant you the liberty not to participate in discourse (I will return to this point). The source of legal rights is the justificatory discourse among equals and its moral basis is the right to justification.

\section{The right to construct rights}

That was quite a mouthful, so let me try to explain what it involves. As abstract as the above considerations may appear, they are also historically grounded. The modern discourse of rights must be understood as arising out of social struggles in which persons or groups demanded concrete improvements of their social standing. But the essential emancipatory aspect of claiming rights was the general claim not to be disrespected in one's dignity as a normative authority who 'deserves' to participate fully in the legal, political and social life of one's society. Thus the language of dignity is deep-seated in these historical contexts, ${ }^{8}$ and historical reconstructions demonstrate that the discourse of rights became the dom-

7 Rainer Forst, The Right to Justification: Elements of a Constructivist Theory of Justice (New York: Columbia University Press, 2012), esp. part one, and Rainer Forst, Justification and Critique: Towards a Critical Theory of Politics (Cambridge: Polity, 2014), ch. 4.

8 Ernst Bloch, Natural Law and Human Dignity (Cambridge, MA: MIT Press); Christopher McCrudden, ed., Understanding Human Dignity (Oxford: Oxford University Press, 2013); Forst, The Right to Justification. 
inant language in which calls for ever-improved forms of equal legal, political and social standing found expression. ${ }^{9}$

Yet, contrary to the common but unfounded opposition between a historically grounded and a moral or even transcendental argument, consideration of the emancipatory point of basic or human ${ }^{10}$ rights shows that historical and sociological reflection on such rights as emancipatory claims and instruments links up with moral and transcendental reflection. For not only must the character of basic rights as realizing a fundamental status as legally, politically and socially non-dominated (and in this sense equal) persons be recognized; in addition, their normative force implies that, among persons who respect each other morally and who seek to embody this kind of respect in law, these rights must be seen as justified horizontally between moral and political equals. This quality is sometimes referred to as 'relational,' though this term must be interpreted in a discoursetheoretical way to emphasize the justificatory nature of that relation. ${ }^{11}$ Basic rights are rights that equal justificatory authorities can always claim to possess and can never deny each other - as addressees and authors of such claims and such rights. Their moral ground is the basic right to justification, or the right to be respected as an equal moral authority, and the substance of these rights is specified when it is determined (in discursive practice) what it means to be recognized as an equal and free normative authority in the legal, political and social realm.

It is important to understand that these rights, even though they aim at a legal, political and social status and can only be justifiably fully determined and realized in a democratic regime, have a 'ground' that is both moral and, if you will, transcendental: the autonomy of persons with a right to justification as a normative authority equal to all others. Basic rights are constructed on that basis, where the agents of construction are autonomous persons, and the principles of construction are principles of justification among equals. ${ }^{12}$ Here we arrive at the reflexive truth about the ground of basic rights: they are rights of and between autonomous equal authorities in the realm of normative reasons, and they express respect for such autonomy and authority, materialized with reference to the legal, political and social world (and the many dangers of domination encountered in that world). Their ground is the respect for each other as moral equals and as justifying beings (using practical reason as the faculty of justification), who are

9 Barrington Moore, Injustice. The Social Bases of Obedience and Revolt (New York: Palgrave Macmillan, 1978); T.H. Marshall, Citizenship and Social Class (Cambridge: Cambridge University Press, 1950); Richard Tuck, Natural Rights Theories: Their Origin and Development (Cambridge: Cambridge University Press, 1979).

10 See Forst, Justification and Critique, ch. 2.

11 Elizabeth Anderson, 'What is the Point of Equality,' Ethics 109, no. 2 (1999): 287-337; Samuel Scheffler, Equality and Tradition (Oxford: Oxford University Press, 2010); Forst, Justification and Critique, ch. 1.

12 Onora O'Neill, Constructions of Reason: Explorations of Kant's Practical Philosophy (Cambridge: Cambridge University Press, 1989); John Rawls, Political Liberalism (New York: Columbia University Press, 1993), ch. 3. 
bound by nothing other than what they can claim from each other as justificatory equals. They are bound and at the same time free as autonomous agents of justification - bound to each other as justificatory equals and to the principle of reason as the principle of reciprocal and general justification for reciprocally and generally valid norms. ${ }^{13}$ So the 'ultimate' justification of these rights is the principle of justification itself. No other values or 'interests' are at play here, only the principle of the right (moral) use of the faculty of justification among equals who are willing to make good on the claims they make on each other as responsible beings.

It is in Kant's philosophy that we find the connection between the prior and 'inviolable' moral status of persons that grounds basic rights and the activist, constructive aspects of this status as being makers and not merely recipients of law. Kant's notion of the dignity of autonomous persons, with its twofold character of calling for unconditional moral respect as equals and for its operationalization in the mode of justification ${ }^{14}$ between legislators in the space of reasons, combines morality, law and politics to ground basic rights. In the realm of morality, Kant explains the status of persons as 'ends in themselves' - that is, as beings whose purposes must be accorded equal respect (within the bounds of reciprocity) and must not be ignored or instrumentalized by others - in terms of the idea of the dignity of a rational being, who obeys no law other than that which he himself at the same time gives. ${ }^{15}$ The beings with such dignity are all equally law-givers and thus have to govern themselves with reciprocally and generally justifiable norms, as the categorical imperative states. To understand why Kant employs the notion of dignity here, it is essential to focus on the 'worthiness [Würdigkeit] of every rational subject to be a law-giving member in the kingdom of ends. ${ }^{16}$ With this, Kant emphasizes the status or rank $^{17}$ of persons as moral equals and as active law-givers - that is, as normative authorities subject to no one or no values other than those which can be justified in accordance with the categorical imperative of their own rational will. The imperative calls on persons to respect each other as justificatory equals. To be respected as an end in itself means not to be subjected to actions or norms that cannot be justified to each person as an equal. As Kant explains in the Groundwork, treating another as a means (for example, by making a false promise) means that the other 'cannot possibly agree to my way of behaving toward him, and so himself contain the end of this action. ${ }^{18}$ Hence, the right to justification and the moral duty to provide justifications express what it means

14 This aspect of Kant's approach is stressed by O'Neill, Constructions of Reason and Habermas's discourse ethics in their respective interpretations.

15 Immanuel Kant, Groundwork of the Metaphysics of Morals, ed. and trans. Mary Gregor (Cambridge: Cambridge University Press, 1997), Academy page 434.

16 Ibid., Ac. 439.

17 The notion of rank is stressed by Jeremy Waldron, Dignity, Rank, and Rights (Oxford: Oxford University Press, 2012); see also the discussion in George Kateb, Human Dignity (Cambridge, MA: Belknap Press, 2011).

18 Kant, Groundwork of the Metaphysics of Morals, Ac. 429-30. 
to respect others as ends in themselves, i.e., as equal normative authorities in the normative realm.

In my Kantian view, the right to justification operates between the moral and the legal-political level. Thus it performs a similar function as Kant's 'innate' or 'original' right of persons. Kant introduces this right as the only 'natural' right of persons and as the ground of every justifiable form of positive law imposed over free and equal members of a kingdom of ends; thus, before explaining the innate right, he stresses the natural legal duty to regard oneself and others as ends in themselves. ${ }^{19}$ In this connection, Kant introduces the innate right as follows: 'Freedom (independence from being constrained by another's choice), insofar as it can coexist with the freedom of every other in accordance with a universal law, is the only original right belonging to every man by virtue of his humanity.' ${ }^{20}$ This right to independence under general law has been interpreted correctly by Ripstein as a right to non-domination and as the "basis of any further rights a person must have. ${ }^{21}$ In this connection one needs to stress both aspects discussed by Kant under the headings of private and public right: the right to legally protected independence and the corresponding right to participate in making the general law that will bind all. These are the two aspects of the moral right to justification in the realm of law and politics: to be bound only by strictly reciprocally and generally valid laws and to be the co-author of these laws, as Kant explains in his republican political theory.

In Kant's view, the form and justification of all rights or rightful claims has to be strictly reciprocal and general in accordance with the general concept of right, which means 'the sum of the conditions under which the choice of one can be united with the choice of another in accordance with a universal law of freedom. ${ }^{22}$ The natural right to freedom, therefore, is not an unqualified liberty right nor the basis for 'deriving' a list of rights or duties or principles of justice; rather, it entails the moral criteria of justification of any rights or justice claim as well as the principle of the free and equal status of all those who are subjects of the law. This is why the right to freedom - or, in my interpretation, the right to justification - is a foundation for a procedural construction of basic rights. A Kantian constructivist view that entails moral criteria for justifying the constructions as well as the standing of the constructing agents must be based on a reflexive notion of the moral right to justification among equal normative authorities; and the innate right expresses such criteria and that standing. Therefore, it is formal and substantive at the same time, the ground of an autonomous construction of right(s). University Press, 2009), Ac. 236.

20 Ibid., Ac. 237.

21 Arthur Ripstein, Force and Freedom: Kant's Legal and Political Philosophy (Cambridge, MA: Harvard University Press, 2009), 56.

22 Kant, The Metaphysics of Morals, Ac. 230. 
A Kantian constructivist view entails two different kinds of normative arguments or two kinds of normativity: first, the normativity of the principles and ideas of practical reason, to use Rawls's language ${ }^{23}$ - that is, on my account, the principle of reciprocal and general justification and the moral notion of free and equal persons as equal normative authorities with a right to justification; and, second, the normativity of the norms (or 'laws') generated by the constructivist or discursive procedure, be it the categorical imperative or a notion of free and equal discourse. In a Kantian view, it is essential that practical reason (in my understanding, justificatory reason) provides the basis for the principles and ideas used, where practical reason is understood as a rational and, at the same time, moral capacity, that is, not just as a matter of knowing how to justify norms, but also of knowing that one is under a duty to do so. That is why the duty of and the right to justification are co-original. In other words, the theory I propose uses the principle of justification itself as the justifying ground for a theory of human rights, which is why I call it a reflexive and autonomous theory: it appeals to no other ground than the normative principle of justificatory reason. ${ }^{24}$

It is important to see that the normativity of constructed norms depends on the prior normativity of the principles and the standing of the agents of construction. One can only get as much normativity out of a procedure as one invests in it from the beginning; this is why categorical imperatives presuppose one basic categorical imperative and why the duty and right to justification are foundational for any justified norm. For the context of justifying rights, this means that any construction of basic rights must rest on a fundamental right itself, such as the moral right to justification or the innate right in Kant's theory. We can call this the principle of the conservation and production of normativity: basic rights are grounded on a fundamental notion of a right to have all those rights that free and equal normative authorities cannot reciprocally and generally deny each other if they want to secure and operationalize that status (as the status of discursive authority and non-domination) in the legal, political and social world. If basic rights are rights that free and equal persons cannot deny each other with good reasons, then their status as free and equal - and the right to this status - is fundamental. Only such a basis can generate the normativity of such rights. The ground of basic rights must not be weaker than their validity claim; rather, it must contain and transmit its normativity to such rights as rights no one can reasonably reject between moral-political equals.

To summarize my main grounding argument: respecting persons as equal normative authorities in the realms of morality as well as law and politics is basic, and that respect implies that every person has a right to justification in the relevant

23 John Rawls, 'Kantian Constructivism in Moral Theory,' Journal of Philosophy 77, no. 9 (1980) and Political Liberalism, ch. 3. See also Rainer Forst, 'Political Liberalism: A Kantian View,' Ethics, forthcoming.

24 Here I use a much stronger moral argument about the grounds of the justificatory procedure than is to be found in Rawls, Political Liberalism, O'Neill, Constructions of Reason or Habermas, as I explain below. 
contexts of moral action or political normative orders. Different contexts and procedures of construction follow from this, depending on whether what is to be constructed are moral norms (moral constructivism) or legal-political norms (political constructivism). Since basic legal norms, which define the legal status of non-domination, claim to be generally and reciprocally binding for all persons equally, the principle of practical reason states that all those who are subjected to such norms have to be equal justificatory agents when it comes to justifying them in accordance with the criteria of reciprocity and generality. Reciprocity means that no one may make demands that he or she denies to others and no one may impose his or her non-generalizable views, interests or values on others. Generality means that all those for whom norms claim to be valid have to be equally involved. Such basic norms and rights constitute the basic framework of nondomination, which then allows for democratic forms of justification of lower-level norms and laws that do not have to be justified in a strictly reciprocal and general way but must be the result of institutionalized justificatory discourse. ${ }^{25}$

Basic rights are not general moral rights, but a subset of reciprocally and generally justifiable legal rights that establish the status of persons as equal normative authorities within a particular normative order and protect persons from being exposed to legal, political or social domination. These rights are based on the basic right to justification, which in this context means being the co-author of all the justifiable rights and duties that apply to you. This is the equivalent of Kant's innate right to freedom (and rights) under generally justifiable law. But the formulation of the right to justification captures the ideas of equal personhood under law and of being a political co-author of laws, as well as the status of being free from social domination in a more complex way than in Kant's version. The right to justification is, so to speak, the right of all rights, because it determines the ground, the form and hence the content of all further rights arguments, whether in the moral or the legal realm (when it comes to basic rights). It is, if we consider rights to be valid and justified claims among persons, the very right implied by the word 'justified.' Thus, it is a condition of the possibility of there being such rights at all - and the basis for the imperative that there should be such rights, as the material expression of moral respect among equal justificatory authorities.

\section{Alternative approaches: interest, will, and Habermas's version of discourse theory}

The justification theory of rights is superior to a number of rival accounts, including Habermas's version of a discourse theory of rights. Let me begin with interest-based theories, which maintain that the function of a right is to further 
the right-holder's interests. ${ }^{26}$ Yet such theories cannot sufficiently ground basic rights without adding the normativity-generating factor of justification by and through moral equals. An interest theory of rights states, to use Raz's formulation, that a person has a right if an aspect of his 'well-being (his interest) is a sufficient reason for holding some other person(s) to be under a duty. ${ }^{27}$ This leaves open the criterion for which aspects of well-being, or which interests, are sufficient to ground a right, and thus attempts are made to narrow down 'essential' interests or generalizable aspects of well-being in order to ground rights. ${ }^{28}$ Raz himself provides a value-based account of such interests, arguing that 'the value of the right to its possessor is its ground. ${ }^{29}$ Thus, his approach could be more accurately called a value theory of rights. In order to justify human rights that affirm 'the moral worth of all human beings' and distribute 'power away from the powerful to everyone, ${ }^{30}$ therefore, universalizable values of the good life have to be identified. But if these values are to have such normative force, my argument goes, they must not only reflect the equal moral status of every person, but also express it by being non-rejectable between such persons who seek to establish their status as legally, politically and socially non-dominated subjects by securing basic rights. And if this is correct, then the normativity of these rights does not rest on some prior account of values or interests, but resides instead in their justifiability between equals who invest their justificatory power in these rights by recognizing them to be non-rejectable, given these persons' moral status as equals and what it requires to secure this status legally, politically and socially. What grounds the normativity of basic rights is the justification arrived at in common by equal normative authorities, not some prior account of value, well-being or the good in which human beings have a basic interest. Note that the thesis that human beings have a basic 'interest' in being respected as equal justificatory authorities is not required for the deontological account that I am presenting; nor can there be any value prior to the constructive justification process between such equals. The right to justification is independent of any interest human beings may or may not have in being respected in that way; we owe that kind of respect to everyone, including those who express no interest in it (for whatever reason). Justificatory equals combine their normative force in and by justifying these

26 For a critique of such approaches, see Leif Wenar, 'The Nature of Rights,' Philosophy \& Public Affairs 33, no. 3 (2005), 223-52. For a general debate between these views, see Matthew $\mathrm{H}$. Kramer, Nigel Simmonds, and Hillel Steiner, A Debate Over Rights (Oxford: Oxford University Press, 2000).

27 Joseph Raz, The Morality of Freedom (Oxford: Clarendon Press, 1986), 166.

28 This unites the very different approaches by William J. Talbott, Human Rights and Human WellBeing (Oxford: Oxford University Press, 2010); James Griffin, On Human Rights (Oxford: Oxford University Press, 2008); Allen Buchanan, The Heart of Human Rights (Oxford: Oxford University Press, 2013) and John Tasioulas, 'On the Foundations of Human Rights,' in The Philosophical Foundations of Human Rights: An Overview, ed. Rowan Cruft et al. (Oxford: Oxford University Press, 2015).

29 Joseph Raz, 'Human Rights in the Emerging World Order,' in The Philosophical Foundations of Human Rights: An Overview, ed. Rowan Cruft et al. (Oxford: Oxford University Press, 2015), 221.

30 Raz, 'Human Rights,' 226. 
rights; an interest theory has to rely on 'justified interest' claims as basic rights claims and thus cannot avoid the priority of the justificatory view.

The main rival theory to interest theories, the so-called will theory of rights, is not really a rival when it comes to the justification of rights. Such theories regard rights as expressions of an individual's freedom or self-determination but mainly focus on the function of rights as a power (in the Hohfeldian sense) to place others under a corresponding duty. As Steiner expresses it:

'The job of rights (...) is to demarcate domains - spheres of practical choice within which the choices made by designated individuals (...) must not be subjected to interference - and to specify those demarcations without reference to the content of the choices to be made within those spheres. ${ }^{31}$

This is mainly a theory about the function of rights, not so much one about their grounds. Thus more particular notions like self-ownership are used when it comes to providing a ground for such rights. ${ }^{32}$ Such proposals, however, do not capture the relational justificatory character of rights. Any legitimate liberty right is at the same time a right justified by way of reciprocity and generality and thus does not express a sovereign claim of freedom; it only expresses freedom under generally justified law, and thus is as much an expression of equality as of freedom. In essence, it is an expression of respect for others as justificatory equals. Thus liberty rights do not rest on a particular notion of freedom, contrary to what many, including many interpreters of Kant, may think. ${ }^{33}$ For, as we saw, Kant's innate right to liberty is essentially a right to justification guided by the criteria of reciprocity and generality. That reflexive right is the moral ground of rights, a right to be respected as a justificatory equal. Will theories do not give adequate expression to this ground, focussing instead on individual sovereignty claims.

This is also made apparent by a classic weakness of will theories, namely that they have no place for unwaivable or 'inalienable' rights. ${ }^{34}$ Since they do not operate with the idea of a morally and reasonably non-rejectable claim to be a justificatory equal, i.e., the right to be such an equal, they find no place for the unconditional right to justification which a person may not be willing to use (for good or bad reasons) but which they can never lose or forfeit, even if rightly accused of horrendous crimes. Thus the theory has no place for the main normativity-generating ground of rights.

Contrary to what is often assumed, the justificatory account does not suffer from another weakness of the will theory - namely that it only regards persons who can actually make use of their individual will and affirm their sovereignty as

31 Hillel Steiner, 'Rights at Cutting Edge,' in A Debate Over Rights, Matthew H. Kramer et al., 238.

32 Steiner, 'Rights at Cutting Edge,' 238.

33 Wolfgang Kersting, Wohlgeordnete Freiheit - Immanuel Kants Rechts- und Staatsphilosophie (Frankfurt am Main: Suhrkamp, 1993); H.L.A. Hart, 'Are There Any Natural Rights?', in Theories of Rights, ed. Jeremy Waldron (Oxford: Oxford University Press, 1984). 
rights-holders. The right to justification, as any truly Kantian account free from empiricist reductionist readings acknowledges, is not grounded on the actual capacity to produce and use justifications but on a moral (or, in Kantian language, noumenal) characteristic of human beings (or what Kant calls 'human nature') as justificatory beings who are owed the duty of justification even though they may not be able to exercise their corresponding right. A moral argument and ascription is not a naturalistic or empiricist one; thus the justificatory theory does not require a kind of 'justification driver's licence' as a precondition for the right to justification. Human beings who are not yet, or are no longer, in possession of their rational powers of justification are equally to be respected as justificatory equals, so that one ought to treat them on the basis of reasons that are justifiable to them given our best accounts of their justifiable interests and needs.

My approach also differs in important ways from the most prominent discoursetheoretical justification of basic rights, that offered by Jürgen Habermas. ${ }^{35}$ An important point of Habermas's argument in Between Facts and Norms is that he turns against the idea of answering the question of political and social justice - and of basic rights as part of that - primarily from the perspective of moral theory. According to Habermas, such an approach (that of Rawls being the main example) is not fully attentive to the complex reality of modern, functionally differentiated societies, and a theory of justice must pay particular attention to the autonomy of democratically legislated modern law. Thus, within societies that are 'post-traditional' in the sense that no unitary horizon of ethical values exists and positive law has become separated from morality, it is not possible to reify the principle of moral autonomy in the form of super-positive principles - in continuation of traditional natural law - and to project them onto law from outside, as a 'higher law,' as it were, which is brought to bear against the political autonomy of citizens. Therefore, Habermas's argument for a non-moral conception of the constitutional state (Rechtsstaat) refers not just to the functional complexity of law, but also - and primarily - to its independent democratic legitimation.

Once moral principles must be embodied in the medium of coercive and positive law, the freedom of the moral person splits into the public autonomy of co-legislators and the private autonomy of addressees of the law, in such a way that they reciprocally presuppose one another. This complementary relationship between the public and the private does not refer to anything given or natural but is conceptually generated by the very structure of the legal medium. Hence it is left to the democratic process continually to define and redefine the precarious boundaries between the private and the public so as to secure equal freedoms for all citizens in the form of both private and public autonomy. ${ }^{36}$

Alongside moral autonomy, therefore, appear the legal autonomy of legal persons as addressees of the law and the political autonomy of citizens as authors of the

35 For the following, see the more extended argument in Forst, The Right to Justification, ch. 4.

36 Jürgen Habermas, '"Reasonable" versus “True",' in idem, The Inclusion of the Other: Studies in Political Theory (Cambridge, MA: MIT Press, 1998). 
law - and it is this dual role that constitutes the core of the connection between the constitutional state and radical democracy, or human rights and popular sovereignty, as Habermas puts it. Legal norms must be distinguished from moral norms not only in that they (a) refer to a limited legal community, but also that they are legitimated in political discourses, which (b) are themselves legally institutionalized, and in which (c) not only moral reasons are entertained; finally, (d) legal norms confront addressees as coercive law. They can, of course, be obeyed on the basis of insight - moreover, they must in fact be created in such a way that they can be obeyed on the basis of insight ${ }^{37}$ - but they also assume legal subjects who act from self-interest and free choice and whose conduct must be regulated in a binding way without reference to moral motives. In this sense, law and morality stand in a complementary and compensatory relation.

Habermas's discourse theory of rights starts from the question of what rights 'citizens must accord one another if they want to legitimately regulate their common life by means of positive law.' ${ }^{38}$ Discourse theory transforms itself from a theory of moral norms into a theory of political legitimacy within a legal order. In order to justify a 'system of rights,' Habermas attempts to provide an answer that goes beyond legal positivism and natural law. On the one hand, normative criteria apply to legitimate law; on the other hand, these criteria are not established by moral principles, but by means of a combination of the discourse principle (which Habermas, unlike me, does not regard as a moral principle of justification, but only as a rational principle for generating validity) and the 'legal form.' Only these two concepts are given prior to the 'citizens' practice of self-determination. ${ }^{39}$ The former states that 'just those action norms are valid to which all possibly affected persons could agree as participants in rational discourses, ${ }^{40}$ and the latter consists in the characteristics of positive coercive law mentioned above (a-d). Habermas does not justify the concept and form of law as such, but accepts it as the result of an irreversible historical development. The combination of the discourse principle and the legal form yields the 'principle of democracy,' which, in contrast to a moral principle of discourse, refers to the conditions for legally constituted, legitimate lawmaking. In order to reconstruct these conditions in a system of rights, therefore, Habermas proposes a reflexive 'circular process': the system of rights contains precisely those basic rights that are necessary first and foremost to legally institutionalize the discourse principle, which is supposed to lead to legitimate law. This yields a 'logical genesis of rights. ${ }^{41}$

This argument can best be understood in terms of the concepts of the legal person as addressee and of the citizen as author of the law. The institutionalization of the discourse principle requires political rights of communication and particiracy (Cambridge, MA: MIT Press, 1996), 121.

38 Habermas, Between Facts and Norms, 82.

39 Habermas, Between Facts and Norms, 127-28.

40 Habermas, Between Facts and Norms, 107.

41 Habermas, Between Facts and Norms, 121. 
pation, which however - formulated as positive rights - leave it up to citizens whether and how they should be used. Hence the reverse side of these rights to exercise public (better: political) autonomy is a corresponding right to private (legally guaranteed) autonomy, that is, the right not to exercise one's 'communicative freedom' by participating in discourse. 'Private autonomy' is thus understood in a particular sense as truly 'privative,' as the right to withdraw from relations of communicative justification, ${ }^{42}$ and in a general sense as a right to exercise freedom of choice within the sphere of what is not legally regulated. This leads Habermas to the thesis that the medium of law as such already implies liberty rights 'that beget the status of legal persons and guarantee their integrity.' 43 Thus, by being legally institutionalized, political autonomy includes the private autonomy of legal persons. Habermas does not let the 'logical genesis of rights' begin with rights to participation, since the legal code - and with it the autonomous subject of rights and law - must exist prior to this step. Nevertheless, this code is only introduced in such a way that it awaits a democratic interpretation and thus at the same time (abstractly) enables democracy and is (concretely) enabled by it. This yields, first of all, basic rights 'to the greatest possible measure of equal individual liberties,' then basic rights that determine 'the status of a member in a voluntary association of consociates under law,' and basic rights to the use of these rights. ${ }^{44}$ These rights of privately autonomous addressees of law are supplemented by rights to political participation, which first afford the addressees the opportunity to legitimately and bindingly determine their own legal status. Finally, rights to social participation, or social rights, are necessary in order to be able to use the first four categories of rights, as opposed to merely possessing them in a formal sense.

It is important that protecting the integrity of persons through the guarantee of individual rights, which secure the greatest possible measure of individual freedom for all citizens, can only be achieved by means of the discourse principle ${ }^{45}$ - i.e., that it is not the legal form alone that accomplishes this, but the discoursetheoretical process of 'giving concrete shape' to the initially 'unsaturated' basic rights. Just as there is no legally institutionalized democratic self-determination without subjective liberties, there are no fair subjective liberties without the democratic legitimation and interpretation of their content. In this way, according to Habermas, the 'co-originality' of private and public autonomy, of 'human rights' (i.e., general basic rights that belong to a legitimate legal order) and 'popular sovereignty,' becomes apparent. Accordingly, basic rights are not morally grounded,

42 'Private autonomy extends as far as the legal subject does not have to give others an account or give publicly acceptable reasons for her action plans. Legally granted liberties entitle one to drop out of communicative action, to refuse illocutionary obligations; they ground a privacy freed from the burden of reciprocally acknowledged and mutually expected communicative freedoms' (Habermas, Between Facts and Norms, 120). On this, see the discussion of the right to 'drop out' of communication in Klaus Günther, 'Diskurstheorie des Rechts oder liberales Naturrecht in diskurstheoretischem Gewande?,' Kritische Justiz 27, no. 4 (1994): esp. 473-74.

43 Habermas, Between Facts and Norms, 128.

44 Habermas, Between Facts and Norms, 122.

45 Habermas, Between Facts and Norms, 123-24. 
but are justified by an internal interpenetration of the discourse principle and the legal form:

'There is no law without the private autonomy of legal persons in general. Consequently, without basic rights that secure the private autonomy of citizens there is also no medium for legally institutionalizing the conditions under which these citizens, as citizens of a state, can make use of their public autonomy.' 46

In my view, we do need a conception of the co-originality of basic rights and popular sovereignty; however, Habermas's argument is deficient because he fails to invest the discourse principle and his account of basic rights with sufficient normativity. Briefly, the problem with Habermas's conception lies in his attempt to justify basic rights - and thus classic liberty rights as well as rights to participation or social rights - in a manner that is too immanent to law by using modern law as a 'fact' without further justification. This downplays the normative importance and reasons for rights to personal autonomy and makes them instrumental to the legal institutionalization of political self-determination. In addition, the imperative to institutionalize such self-determination is insufficiently founded, for lack of a right to justification as a moral foundation.

But, what is more, Habermas's theory lacks a unified normative ground. Not only does he not provide moral arguments for rights to personal autonomy or for the discourse principle itself, which he only regards as a principle of normative validity; he does not provide any common normative ground that explains their common origin either. Thus his thesis of 'co-originality' is split between two different origins, the legal form and the discourse principle. My suggestion overcomes the dualism of two origins and provides the right to justification as the only ground for both rights of personal and political autonomy, and thus provides a single and properly moral ground for these rights. Thus, it is a superior account of co-originality - and in terms of classical Frankfurt critical theory, a more dialectical one. I want to insist that basic rights and principles, which must be morally justified in discursive terms, maintain their moral content even if they can only become legitimate law via politically autonomous lawmaking, and even if they were justifiable as implications of the legal institutionalization of the discourse principle (which I do not have to deny). The moral content must, and this is the point to be stressed, enter into the basic structure itself via political procedures of justification. But the moral reasons for basic rights and for procedures of justification between equals remain in place without thereby forcing law under a set of moral rights defined in a priori terms as an 'external' morality.

As I indicated in the above section, we need to distinguish between two stages of moral and political justification (and construction) of basic principles. These two stages must be integrated in such a way that the former can be identified as the 
logical and normative core of the latter, that is, of every justification of a concrete political and social basic structure. The moral justification of rights, whose recognition persons owe one another, cannot be entirely assimilated into a reconstruction of the normative implications of the legal institutionalization of democratic self-determination; nor can the latter process be confronted by these rights or principles as a reified form of morality that only needs to be reproduced within a legal reality. Rather, if free and equal citizens are to mutually justify and legally institutionalize a basic structure that can claim to be just, then the principle of justification must be situated within moral and political contexts such that these contexts are partially (though not completely) congruent. For arguments for basic rights including the right to democracy are moral arguments, and they remain so in any context of law and politics in which they are claimed. ${ }^{47}$

\section{Basic rights as congealed justifications}

The question of the justification of basic rights should be phrased differently than Habermas does. The question is which rights citizens should accord each other if they want to transform the basic respect they owe each other as justificatory equals into a complete system of rights required to secure a legal, political and social standing of non-domination. Thus their moral authority as justificatory equals travels, as it were, toward the normative powers that these rights confer on citizens, without in the process moralizing law or confronting citizens with a predefined set of norms that constrain their political autonomy (since the rightful exercise of such autonomy must not violate the basic forms of respect for each other). Legal rights are still legal rights which do not impose a moral use or a moral motivation for using these rights; nevertheless, they are supported by moral reasons. They become legitimate legal rights only through appropriate procedures of democratic justification; but moral arguments have their place within these procedures.

Basic rights should be regarded as congealed and solidified justifications that express the status of moral equals in the legal, political and social world as free from domination. The justification of each individual right, despite the general moral background, is a 'grounded' and contextual exercise, since a number of historical normative experiences and justifications are sedimented when it comes to such basic rights as freedom of religion, political participation or access to education. To claim such rights means to use these congealed justifications as normative powers in a contested space of justification and to be able to use them as a 'package' without having to justify them anew every time. They provide a safe and

47 In his response to my critique, Habermas affirms that the insight of (imaginary) 'founders' of a constitutional state that an autonomous association of free and equal citizens can be constructed only by means of modern law and on the basis of individual rights that deserve recognition, and thus are discursively generated' (Jürgen Habermas, 'Reply to My Critics,' in Habermas and Rawls: Disputing the Political, ed. James G. Finlayson and Fabian Freyenhagen [New York: Routledge, 2011], 296) is a conceptual and not a moral-political insight. I doubt that, as the language Habermas uses here indicates the normative arguments for such rights. 
secure status or standing in the social world. The basic right to justification enables individuals to take ownership of these justifications, as it were, and to use them to ward off illegitimate power claims - but also to contest these justifications when they are open to the suspicion of being one-sided or narrow. So the right to justification, as a 'veto right' against false justifications, as a particular, higher-order normative power not just to use but also to co-determine rights, is always in place, whereas the content of basic rights is fixed to some extent but is still open to being questioned. Yet all such questioning is bound by the criteria of reciprocity and generality as criteria of practical reason. Thus, to reiterate these criteria, no one may make a claim he or she denies to others (reciprocity of claims) and no one may impose his or her interests, needs, perspective or convictions on others who could reasonably reject them (reciprocity of reasons). Finally, no subjected person may be excluded from the relevant justification community (generality). In a moral-political sense basic rights thus serve, especially within a constitutional regime, as veto rights against legal, political or social arrangements that are unjustifiable and violate these rights; but they can have such normative force only insofar as they express the basic right of justification. This is why declarations and formulations of human or constitutional rights have a higher-order status, though one that is not immune to questioning or revision. Whether there is a right to personal property and whether it entails a right to own means of production (and in what way) are part of that discourse, as well as, for example, what the right to the free exercise of religion entails with respect to the education of one's children. None of the formulations or interpretations of basic rights is 'absolute'; yet the justificatory threshold of unpacking and criticizing them is high.

There are two ways to argue for basic rights. A status-based argument shows how certain basic rights are necessary to institutionalize and secure the very status of being a justificatory equal free from legal, political or social domination. A reciprocity-based argument shows how certain rights claims cannot be reciprocally and generally rejected among equal justificatory authorities. The second characterization is broader than the first, because in this case arguments do not point directly to the status-implications of certain rights as does the first justificatory strategy. Examples for the first group of rights are basic rights to life, bodily integrity, personal liberty, equality before the law and a fair trial, gender equality, non-discrimination, freedom of expression, freedom of collective action including political protest, freedom of political participation as an equal, freedom of movement, the right to citizenship, to means of social subsistence and a minimum standard of social life, and to protection against cruel punishment. Examples of the second group are rights to religious liberty (of belief and practice), freedom of the press, to artistic expression and scientific inquiry, to educate one's children and to education more generally, to privacy, to work and to exercise an occupation, and to personal property. Neither group of rights includes any 'absolutes' but only specific rights within the bounds of reciprocity and generality; for example, there is no absolute right to personal liberty at the expense of the non-domination rights of others, nor is there any prior or 'natural' definition of the right to property and 
what it entails. Every right in the abstract and in its concrete form needs to be justified as a claim that is non-deniable between justificatory equals who aim to establish a status of legal, political and social non-domination by way of basic rights (as part of a basic structure of justice more generally). Thus these rights constitute an important part of what I call fundamental justice. ${ }^{48}$

Apart from the distinction between two ways of justifying basic rights - namely, directly and indirectly - we also need to distinguish between two levels of justification and specificity (as already mentioned in the last section). On a first, moralpolitical level, a conception of generally defined basic rights needs to be specified such as we find in human rights declarations or (somewhat more concretely) in constitutions, leaving the concrete determination to be specified by law - provided that (on that first level) it is laid down that any such specification has to be a matter of realizing basic rights within what I call a basic structure of justification. This first level is that of moral-political constructivism.

On a second level, which is a combination of moral, political and legal construction, the particular content of basic rights must be specified discursively. For example, whereas on the first level the reasons for a right to democratic political participation are regarded as non-rejectable, the task at the second level is to determine how this can be realized in such a way that the moral status of being a justificatory equal acquires the best possible legal and political expression - though this can vary across different kinds of democratic systems (representative systems, council systems, direct democracies, and so on). The distinction between two levels of construction does not mean that the second merely 'applies' or 'mirrors' 49 a fixed set of morally preconstructed rights; rather, the political constructions of basic rights on this level specify and interpret what it means in a given political community to have freedom of speech, a right to political participation, a right to a decent social status, and so forth.

I cannot enumerate the whole list of rights, so a few examples must suffice. The right to individual liberty - or, as the German Basic Law puts it, the 'freie Entfaltung der Persönlichkeit,' i.e., the free development and expression of one's personality - is non-rejectable between persons who respect each other as justificatory equals and independent authorities in the realm of reasons, or, in Rawls's terminology, as 'self-authenticating sources of valid claims. ${ }^{50}$ Contrary to what many liberal theories argue, this does not presuppose that such liberty is a precondition for a good life based on self-reflection and self-determination; Kantian views are not committed to theories of the good life of this kind. Rather, individual liberty is justified by the basic respect for others as normative equals who would be subjected to domination if some members of society were in a position to define the liberty of others in terms of reasons that can be reciprocally and

49 This is the worry of Buchanan, The Heart of Human Rights, 14-23.

50 Rawls, Political Liberalism, 72. 
generally rejected, for example in terms of religious reasons that are not sharable or paternalist considerations that purport to reflect the 'true interests' of others who do not share them. Such forms of respect resonate with a certain notion of dignity as a justificatory authority equal to others, and the justifications congealed in basic liberty rights that contest restrictions on individual liberty involving domination express this status. These justifications do not exclude legitimate reasons for restricting such liberty or freedom; the German Basic Law, for example, adds that the right to personal liberty presupposes that one does not violate the rights of others, as is obvious from a Kantian structure. Within that structure, there are no 'natural' basic rights apart from the fundamental rights claim to all of the rights that can be reciprocally and generally justified. Thus there is no 'natural' right to liberty at work here, contrary to Hart, ${ }^{51}$ for example, since every liberty claim has to be justified socially and intersubjectively. In addition, the argument does not amount to a libertarian 'presumption of liberty, ${ }^{52}$ that is, to the assumption that there is a prior and primary claim to unconstrained liberty and a special threshold for secondary constraints on that fundamental claim. The true fundamental claim is not one to unconstrained liberty but to respect as a justificatory equal to others. This is as much a claim about liberty as it is a claim about equality, and in essence it is a claim to a normative order of justice, where every liberty claim must be justifiable to others as equals. ${ }^{53}$ This does not mean, as some might fear, ${ }^{54}$ that only justifiable forms of freedom are called freedom; rather, it means that, within a political normative order, one has a legitimate claim only to exercises of freedom (what Kant calls Willkür and what we can still call freedom) that do not violate the respect owed to others as non-dominated equals.

It is interesting to note that the German Basic Law (Article 2.1) adds that one is free in one's personal liberty as long as one does not violate the rights of others or the constitutional order or the 'Sittengesetz,' the moral law. Whatever is meant by this exactly, this qualification is unfounded. For if it refers to some form of public mores or customary codes of decent behaviour (to which laws against homosexuality have traditionally appealed, for example), it is not reciprocally justified as a reason for restricting liberties; and if it refers to the Kantian moral law it is also inappropriate, for even if that moral law grounds the basic status of others as normative equals that is foundational for basic rights, it also regulates many areas of private life that the law ought not to regulate. For example, there is no basic legal right that others should always tell you the truth, even though there is a moral imperative not to lie. The moral law does not translate directly into a sys-

51 Hart, 'Are There Any Natural Rights?'.

52 Jürgen Neyer, 'Justice and the Right to Justification: Conceptual Reflections,' and Alexander Somek, 'The Preoccupation with Rights and the Embrace of Inclusion: A Critique,' in Europe's Justice Deficit?, ed. Dimitry Kochenov et al. (Oxford: Hart, 2015).

53 Forst, The Right to Justification, ch. 5.

54 Laura Valentini, 'Kant, Ripstein and the Circle of Freedom: A Critical Note,' European Journal of Philosophy 20, no. 3 (2012), 455 and Christian List and Laura Valentini, 'Freedom as Independence,' Ethics 126 (2016), 1043-74. 
tem of basic rights, and moral considerations do not dominate the use that persons can make of these rights. Respecting others' rights is morally required; but it also includes respecting their standing as autonomous and non-dominated individuals free from moral policing. If the law sought to sanction every breach of a promise (or every insult) in private and social life, for example, its normative order would be in danger of becoming a dystopia of control and constant litigation.

The right to political participation, to take another example, is of special importance in a discourse-theoretical approach. For it expresses our standing as normative equals and authorities in the space of social reasons in a particular way: it is an expression of that dignity and confers a higher-order normative power on persons as co-authors of the law, thereby generating reflective pressure within a normative order to make its institutions of participation and decision-making more open and inclusive. The normative power of political autonomy is of a higher order than the Hohfeldian normative power to change other people's legal powers by selling them an object I own, for example. ${ }^{55}$ For it is the normative power to co-determine the framework within which such lower-order changes in power occur.

As Klaus Günther has argued, the right to political participation and expression (to include that aspect) is normatively connected with the right to personal liberty, for to be respected in your 'communicative freedom' to be the source of valid claims also means to have the right and opportunity for social and political expression and participation. ${ }^{56}$ These are two sides of the same coin, namely to have standing as an autonomous author and addressee of the law; yet, contrary to Habermas (as argued above), rights to personal liberty are not just the negative implication of the legal form required to institutionalize the discourse principle. At the same time, it is important that the right to political participation is not reified into a legal duty of participation. The political community must not exclude anyone from participation but must leave it open to citizens to decide whether they want to participate as part of their political liberty.

An important implication of the higher-order normative power of the right to political participation is that to be fully respected as a non-dominated equal means that one can be the co-author of the concrete legal normative order of rights to which one is subject. This is an implication of the reflexive character of basic rights as grounded in the right to justification. Thus rights justified in this way do not constrain but instead constitute political autonomy as the exercise of justification among equals. So the concern expressed by Habermas that a moral argument for basic rights questions the political and legal sovereignty of citizens is unfounded; all of these rights are justified and determined in an appropriate discursive practice. Basic rights determine a just basic structure and are deter-

55 Hohfeld, Fundamental Legal Conceptions, 52.

56 Klaus Günther, 'Die Freiheit der Stellungnahme als politisches Grundrecht - Eine Skizze,' in Theoretische Grundlagen der Rechtspolitik, ed. Peter Koller et al. (Stuttgart: Franz Steiner, 1992), 58-73. 
mined by it, depending on different levels of abstraction; their general content can be justified in a counterfactual way, while their particular content must be justified in justification procedures among political equals free from domination. Establishing a justified system of rights is a never-ending reflexive exercise. That is a hermeneutically virtuous, not a vicious circle.

Social rights as rights to participate in social institutions, from the workplace to educational systems and other areas of life, therefore, are not justified in instrumental terms as required to realize the 'fair value of liberties' (Rawls) or the other categories of rights (Habermas). They are intrinsically justified as rights to prevent social domination and to be a social equal in fundamental respects. Domination assumes many forms, and being easy prey to economic exploitation is a clear and long-standing danger to which a definition of basic rights must respond. Again, there is no notion of the minimally good life at work here. Rather, the main reason for such rights is to endow every person with a basic standing that provides him or her with protection against different forms of social domination, ranging from economic exploitation to oppression in familial structures. Then the right to social goods such as food, housing, education and medicine is no longer primarily a right to certain means of subsistence, but is instead a right to a social standing at least to the extent of being a full member of society. In addition, it must be emphasized that such rights are far from being the only means of furthering social justice; the economic order, as an important part of the normative order, is fully subject to processes of political justification, and the criteria of reciprocity and generality give each person, including the worst off, a veto right against unjustifiable economic arrangements. ${ }^{57}$

The right to religious liberty is a good example of the second, indirect justificatory strategy. People who respect each other as justificatory equals accept that they must not impose values or beliefs, such as religious beliefs, on others who reasonably disagree with those beliefs. Imposing religious or antireligious views violates the reciprocity of claims and of reasons, because to do so is to claim a privilege (using the force of law to generalize one's own reasonably rejectable beliefs) and dominate others. And if the justification community is restricted to fellow believers only, generality will be violated. ${ }^{58}$ Thus the right to religious freedom, as it evolved and became established in the course of the long history of religious conflicts, is a basic right that both protects persons against religious oppression and discrimination and grants them the positive liberty to live in accordance with and express their beliefs, including the right to the communal practice of religion. (Thus it is not true that such rights involve an individualistic mindset.) The reason for this is not that religion is a value as such, but because the right to religious liberty is a basic right of legal, political and social non-domination among equals who respect each other's views and identities. And to exercise that right also means that the way in which it is exercised is not defined by dominant reli-

57 See Forst, Right to Justification, ch. 8.

58 See Rainer Forst, Toleration in Conflict. Past and Present (Cambridge: Cambridge University Press, 2013). 
gions but such that all religions have the right to practice their religion in their own way as long as they do not violate other rights.

Another example of a reciprocity-based justification of basic rights is the right to personal property. Again, there are no 'natural' rights at work here as implied by Lockean arguments of extended self-ownership, and Kant cannot be interpreted in such a libertarian sense either, as I argued above. Any right to personal property is in need of justification, and the best argument is that such a right is an important protection against domination by persons who deny others their secure space and place in the social world and arbitrarily deny them what they require or have created. But any concrete form that such a right assumes must be reciprocally and generally justifiable. Thus, a right to possess means that confer the power to structurally exploit others, as entailed by the unrestricted right to ownership of the means of production, cannot be a basic right.

To take a final example, the right to privacy is an important right insofar as it specifies the general right to liberty that enables individuals to live an autonomous life free from dominating interference, whether by persons or institutions such as companies or the state. Such a right is in part a response to new possibilities of technological control in a digital society which covers hitherto unregulated areas such as internet data. It is also another example which demonstrates that a moral reason for such rights does not imply a moralized use of them. For in exercising the right to privacy one must not violate other people's rights; but one does not lose this right by pursuing morally blameworthy goals. There is no paradox in arguing on moral grounds for (legal) rights to commit amoral or even immoral acts as long as the (legal) rights of others are respected.

\section{Rights as means of domination}

Rights are not an innocent form of the exercise of normative power. They can be used to defend oneself against domination; but they can also be used as means of domination, for example when a multinational company obtains property rights in the natural resources of a country whose inhabitants then become dependent on and (potentially) dominated by that company. ${ }^{59}$

But even more generally, ever since Marx's critique of bourgeois rights as the instruments of egoistic monads, the critique of the dominating implications of rights has gone deeper. They are seen as an important part of a social imaginary that separates people from each other and imposes an instrumental form of reasoning on them, so that people are mainly asking themselves whether their rights are sufficiently respected and how they can increase their normative powers

59 Turkuler Isiksel, 'The Rights of Man and the Rights of the Man-Made,' Human Rights Quarterly 38, no. 2 (2016): 294-349. 
against possible encroachments on their normative space. ${ }^{60}$ The moral individualism of rights, it is argued, gives rise to a social form of possessive individualism. ${ }^{61}$

At this point, I cannot discuss the Marxist, feminist or communitarian versions of this critique. ${ }^{62}$ But there can be no doubt that an emancipatory instrument like rights as powers against non-domination can become transformed into its opposite, that is, into a means of domination. But in the light of such a (negative) dialectics of rights, we ought to hold on to the main insight of the discourse-theoretical view: that no rights or no use of rights can be justified that violates the basic respect among justificatory equals as non-dominated persons. So here, as in other contexts, the ideology of domination dressed up as libertarian freedom must be exposed, criticized and overcome. One way to do this could be to look for a normative order of justice that operates without the notion of rights, though it would still have to contain normative concepts for the protection and realization of justifiable claims with that order. ${ }^{63}$ But another, and for the time being more realistic way is to insist on the horizontal justificatory character of basic rights and their reflexive nature, which implies that persons are not the objects but the subjects of a rights order - in fact, that they are its highest authority. Rights talk is only one way to express this, though a very powerful one. And we understand that power best when we consider the reflexive grounding of basic rights: if we are looking for a firm basis for reciprocally and generally justified basic rights, then the very principle of reciprocal and general justification and the right to justification is the place to look for such a ground. Only that ground binds the content of such rights to the imperative of non-domination and equal respect, and only such a ground binds individual rights to the practice of democracy as justification between equals - a practice, to be sure, that does not yet exist.

60 Wendy Brown, States of Injury (Princeton: Princeton University Press, 1995); Christoph Menke, Kritik der Rechte (Berlin: Suhrkamp, 2015); Axel Honneth, Das Recht der Freiheit (Berlin: Suhrkamp, 2011).

61 Crawford B. Macpherson, The Political Theory of Possessive Individualism: Hobbes to Locke (Oxford: Clarendon, 1962).

62 Rainer Forst, Contexts of Justice (Berkeley: University of California Press, 2002). 